\title{
Kindergarten Students Acquire Basic English Literacy Through Letterland: A Case Study
}

\author{
Joice Ellen Limbong \\ Coordinator of Kindergarten Teachers \\ Mentari Intercultural School - Grand Surya, West Jakarta
}

\begin{abstract}
This study aims to help kindergarten students to acquire basic literacy in English through the use of Letterland which is believed to be a fun and exciting program which can produce a natural outcome. This study utilizes qualitative and quantitative approach. The research design of this study is case study in order to make intensive analysis on how kindergarten students acquire Basic English literacy through Letterland. The study presents a description on how effective and helpful Letterland is in helping kindergarten students acquire basic literacy. This study can be used to provide local teachers or educators with the ideas in implementing the phonics approach in teaching Basic English literacy. There are number of factors that enable students to acquire the Basic English literacy; however, this study focuses on the application of Letterland. Findings showed that Letterland is useful to help kindergarten students in school $\mathrm{K}$ in acquiring Basic English literacy. Students recognized the initial, medial and final sounds. The teachers implemented Letterland with a proper class settings, sufficient teaching aids, and proper teachinglearning process.
\end{abstract}

Keyword - Letterland, Basic English Literacy, Kindergarten

\section{INTRODUCTION}

Literacy has a broad concept; to many people, it is simply the ability to read and write a text. Therefore, students are usually expected by their teachers to comprehend reading texts. Students are expected to be smart readers who are able to effectively comprehend the text. (Katemba C. \& Samuel 2017). This is a key issue (Poulson et.al. 2010) for education policy in many countries. Garton and Pratt (1998, p.1) defined literacy as 'the mastery of spoken language and reading and writing.' It is one of the reason to advocate children to read and write once they have reached the ability to speak. The basic literacy, according to Randhawa (2012), is possession of practical competence to acquire the reading and writing skills. Cameron (2001) stated that learning literacy may start from kindergarten level or at the age of four years old. However, teaching four-year-old children basic literacy is not that simple. It requires specialty in order to stimulate children's curiosity in learning. Piaget (cited in Cameron 2001) added that children are active learner and thinker who construct their knowledge from working with objects or ideas. In that case, teachers should be responsibility to help their learners to be able to read and write in a stress-free environment.

Nowadays there are many kinds of reading and writing programs offered to schools. One of the program employs phonics which is widely used in schools to teach students Basic English literacy. In this regard, Smith (1982) explained that phonics instruction aims to help leaners read with rules that will assist them to predict the sound of the written word from the way it is spelled. There have been several studies about the use of phonics in teaching kindergarten Basic English literacy. Maharani (2007) focused in her study on applying Synthetic Phonics on teaching reading to children. Synthetic phonics emphasize the learning of English sounds. Meanwhile Anita (2008), in her investigation on teaching reading to kindergarten students, utilized Synthetic and Analytical Phonics teach reading through phonics. She claimed it to be successful and useful in teaching reading. Campbell, Torr, and Cologon (2014) stated that in early childhood settings, language-rich environment is key to having overall quality, including children's interaction around picture books and dramatic play. In a language-rich environment, phonics program is useful and meaningful to help children learn alphabet letters and sounds. Therefore phonics is considered to be effective in 
teaching reading to kindergarten students as it provokes phonological awareness which lead children to possess natural outcome in reading.

The studies above have encouraged the researcher to investigate further the use of phonics programs in teaching children Basic English literacy. She found out that there are several phonics programs: Hooked on phonics, Jolly Phonics, Wilson Reading System, Jump Start Phonics, and Letterland; of all the phonics programs, Letterland becomes the focus of the study. It is one of few published teaching programs which uphold the central importance of phonics. Aside from that, Letterland is one of the phonics programs in helping kindergarten students to acquire not only reading skills but also writing skills. Thus, this study attempts to seek the answers on how kindergarten students acquire basic English literacy through Letterland and to what extent does Letterland help students acquire their Basic English Literacy.

\section{Brief Overview on Letterland}

Letterland is considered as child-friendly phonics. It was developed in England in 1968 by Wendon. She claimed that this phonics program has existed for more than forty years and it has been widely used by many schools or institution to teach language to their students as in sense general and to teach the Basic English literacy. Letterland is described as a 'system for teaching children the basic literacy; namely how to read, write and spell using a synthetic phonics approach. The key words in the definition above are 'system' the 'basic literacy' and phonics' those three key words describe what Letterland is all about. Letterland is set in an imaginary place called Letterland, a land populated with twenty-six pictograms-based characters. These characters are a fusion of letters and animated characters. Each character has its story which aims to make students feel happy because of the funny and interesting story. By using the story, the teacher may lead students to sound each letter, write letters in correct strokes, mentioning some vocabularies that start with certain letters, and finally to be able to write and read simple words and sentences.

Story-telling is the essence of learning with Letterland because stories as stated by Wray and Medwell (1991) that stories allow young learners to learn about things and people that will stimulate their imagination which enable them to develop their language usage in several ways. In process of giving story-telling, the students are expected to be curious of what character or letter is to be discussed in the next segment. Smith (1982) described Letterland as 'straddling the ebb and flow of controversy concerning the best method for teaching literacy skills, and reading letters and a happy collaboration between teachers and children in the language build around this learning.' This happy collaboration is achieved through the story of each character in Letterland.

In utilizing Letterland, teachers should understand the correct steps. According to Wendon's (1999) guide book on Letterland, there are three books of program on Letterland. The first guide book is for the younger students at the age of 2-3 years old. In this program the students are introduced to all the Letterland charcters and are instructed to focus on initial sounds. Such as 'M' for Munching Mike, 'B' for Bouncy Ben. The introduction of each character is accompanied with a simple story of the character being discussed.

After the early years program, the students will go to the next level, namely Program One in which the students learn more about each characters in Letterland. They also discover in this program that the sounds of the letters can be found easily when they start to pronounce the characters' names. Moreover the students at this level will learn how to recognize and trace each shape of the letter, followed by producing correct letter formation. The effect is a simultaneous reinforcement of both shape and sound in any given word. This means that student will be able to acquire some vocabulary starting with the sounds of certain letters, such as candy, can, cake, candle, and cap as they learn 'c' or Clever Cat as one of the letters or characters in Letterland. Program One also teaches students to put letters together to form blends and finally read consonant-vowel-consonan (CVC) words, such as cap, fin, jog, bug, and wet. 
Letterland offers a variety materials or teaching aids to support the activities. The essential materials for this program are: Teachers' Guide Books, Early Years Handbook, Program One Handbook, Program Two Handbook, Tape and CD, ABC Books, Class Wall Frieze, Workbooks, Picture Code Cards, Copy Masters Books, and other teaching aids. Therefore, in conducing this study, the researcher has equipped herself with all these materials.

\section{LITERATURE REVIEW}

An illiterate child will automatically not be able to access the latest news or to read information about what is happening around him or her. Daswani (1999) accentuated that basic literacy skills are very imperative to be acquired by every child. Since the basic literacy skills are very important, teachers should think of various literacy strategies to teach basic literacy in an easier way and, of course, in a painless way. Teaching basic literacy to kindergarten students is such a complex thing to do; Cameron (2001) said that to teach second language to a young child is complicated. In that case, there are several researchers that have conducted some research on how to teach basic literacy. Most of their research led to phonic method; it is considered to be important in teaching basic literacy.

\section{Phonic Approach}

Widdowson (1971) discovered the advantages and disadvantages of using phonics in teaching reading and writing. He noted that the main advantage of using phonics is that the method interferes with idea of grasping words, phrase and sentences as a meaningful language units. Furthermore, Weaver (1994) stated that phonic method leads to phonemic awareness; where the learners begin to distinguish letter sounds. Phonemic awareness is essential for literacy development as phonics is frequently taught. Pressley (2006) added that phonemic awareness is defined as the awareness that words are composed of separable sounds that are blended to produce words. Before children learn to read words, they need to have some degree of awareness to study how the sounds work.

\section{Teaching Reading as Basic Literacy Skill}

Reading is a very essential element in teaching a child. There are many aspects that teachers need to know about how the reading skill is acquired by children. Blevins (2001) suggested that the process of learning to read among young learners should cover the following skills: The concept of print, Alphabet recognition, Blending Letters, Sense of Story, and Builidng Knowledge. Llyod (1992) mentioned five key elements in reading process; they are: Learning letter sounds, learning letter program, blending for reading, identifying the sounds in words, and Learning Tricky words. The reading process given by Blevins and Llyod have the same process with what Letterland has. In Letterland, The children are taught first about the alphabets recognition and continue with the sounds of each letter, then recognize the five vowels and the blending sounds that is three letter words or what so called CVC blends.

\section{Teaching Writing as Basic Literacy Skill}

Piazza (1987) said that learning to write is much more on a process that children may progress from one phase to the net. Learning to write requires the learner to move a pen or a pencil and render letter precisely. Once the student is able to grip his or her pencil and write the alphabets, the simple words, simple phrases and simple sentences, he or she will be able to proceed to the higher level where they have to remember the rules of English grammar and syntax, then to place their thoughts in order. Cook (2004) explained that when children learn the writing system of English, they will encounter all the complexities of English. Additionally, Gentry (1982); Clay (1975) and Green (1990) stated that in teaching writing to children, teachers should recognize the eight stages in writing: a) Stage 1 - Scribbling; b) Stage 2 - Letter-like Symbol; c) Stage 3 Strings of Letters; d) Stage 4 - Beginning Sound Emerge; e) Stage 5 - Consonants Represent Words; f) Stage 6 - Initial, Middle, and Final Sounds; g) Stage 7 - Transitional Phases; h) Stage 
8 - Standard Spelling. The stages of writing using Letterland program are more or less the same as the principles that have stated by Gentry, Clay, and Green. By recognizing steps of writing, the children will be able to write first letter they hear or known as beginning or initial sound.

\section{METHODOLOGY}

This study utilizes qualitative approach because it can be applied through class observation. The research design of this study is case study. The subjects of this study were kindergarten students and teachers who used Letterland to teach and learn basic literacy. There were forty six students from three parallel classes of kindergarten, with range of age four to five. The parallel classes were $\mathrm{K} 1-\mathrm{A}, \mathrm{K} 1-\mathrm{B}$, and $\mathrm{K} 1-\mathrm{C}, \mathrm{K} 1-\mathrm{A}$, and $\mathrm{K} 1-\mathrm{B}$ and $\mathrm{K} 1-\mathrm{C}$.

The data were collected in two ways, namely by using class observation and test analysis. The researcher visited all the three parallel classrooms. The observation was conducted through some sessions of teaching. The researcher observed the students and teachers during their teachinglearning activities. There were around 10 to 15 visits to the classrooms. During the class observation, the researchers observed how the students responded to the lessons, what activities the teacher and student did, and the teaching aids that were utilized by the teachers. The class observation for the classroom was carried out in two semesters, from August 2006 until June 2007. In one week, there were three sessions of meeting with forty-five minutes in each session. The purpose of doing the class observation is to know the process of kindergarten students in School $\mathrm{K}$ acquire Basic English literacy. The items that were parts of the observation are Teacher's teaching style, teacher's syllabus, classroom setting, and teaching aids.

After conducting the class observation, the researcher went through administering a test. The test was given after the students learned all the topics: alphabets and letter sounds. The test is not to test students' basic literacy yet it is only to analyze students' scores and the items of the test. There were eight kinds of tests given to the students: Correct Letter Information, Initial Sound, Medial Sounds Final Sounds, Initial and Final Sounds, Medial and Final Sounds, Rhyming Sounds, and Short Phrases. Each test represented skill of Basic literacy which allowed students to read $\mathrm{CVC}$ words, short phrases and simple sentences which was conducted during the other session of observation.

\section{RESULTS AND FINDINGS}

Letterland helps learners in school $\mathrm{K}$ acquire basic literacry. The characters in Letterland attracted students' attention in the classroom because it had several activities which encountered students' boredom. The followings are analysis of Class observation and 


\section{Class Observation}

The class observation is about classroom settings, task implementation, teaching aids, and teaching-learning process in school. The following is the summary of class observation:

\begin{tabular}{|c|c|}
\hline Items & Observation \\
\hline Classroom Setting & $\begin{array}{l}\text { Each Class has } 4 \text { bulletin boards Each teacher display } \\
\text { twenty-six Letterland characters in one bulletin board with } \\
\text { various themes, such as garden, sky and sea theme. The } \\
\text { other bulletin boards displayed four weathers with eye- } \\
\text { catching pictures, birthday charts of students, and students' } \\
\text { works. During the observation the students' attention was on } \\
\text { the boards. } \\
\text { Another setting that caught the researcher's attention was } \\
\text { posters that appeared in every classroom. There were } \\
\text { various kinds of posters. } \\
\text { At two corners of the classroom, there were playing zone } \\
\text { and mini library. In the playing zone, the teacher provided } \\
\text { one small rug with two shelves contained various kinds of } \\
\text { toys such as puzzle, blocks, car, dolls, and so forth. } \\
\text { Meanwhile the mini library displayed many English story } \\
\text { books, Indonesian Story Books, as well as Bible story } \\
\text { books. } \\
\text { Each classroom consisted of four rectangular tables with } \\
\text { small portable chairs and one big rug facing the big portable } \\
\text { whiteboard. }\end{array}$ \\
\hline Teaching Aids & $\begin{array}{l}\text { There were various teaching aids that were utilized by the } \\
\text { teachers in implementing Letterland. Each teacher provided } \\
\text { Flash Cards, Pictures of words, boxes of attractive objects, } \\
\text { picture code books, and story books. } \\
\text { During the observation, mostly the students were interested } \\
\text { in seeing real objects rather than Flash Cards or Word } \\
\text { Pictures. Therefore teachers provided CD to help learners } \\
\text { recognize the characters in Letterland which somehow } \\
\text { encouraged them to learn the sound of letters through songs. } \\
\text { However during the observation, the researcher found out } \\
\text { that the teachers did not fully utilized the teaching aids to } \\
\text { introduce the characters in Letterland. The teachers should } \\
\text { have maximized all the teaching aids in the classrooms to } \\
\text { support the teaching-learning process. }\end{array}$ \\
\hline $\begin{array}{l}\text { Teaching-learning } \\
\text { Process }\end{array}$ & $\begin{array}{l}\text { The teachers started to teach their students the recognition of } \\
\text { letter-sound relationships. They considered it to be essential } \\
\text { to decode an unknown words or to encode a word when } \\
\text { writing. The teacher introduced each letter through a story- } \\
\text { telling. In Letterland, all the twenty-six alphabets have their } \\
\text { names such as 'a' for 'Annie Apple' and ' } b \text { ' for 'Bouncy } \\
\text { Ben'. All the names or characters have their sounds. During } \\
\text { the observation, the students were able to familiarize names } \\
\text { of each character or letters. In fact, the students became more } \\
\text { and more fluent in sounding the letters. } \\
\text { In the observation, the teachers introduced writing of upper } \\
\text { and lower case letters to the students. The students were able } \\
\text { to practice the letter-sound relationship through games, and }\end{array}$ \\
\hline
\end{tabular}




\begin{tabular}{|l|l|}
\hline & $\begin{array}{l}\text { finally they learned how to blend the sounds, read the CVC } \\
\text { words, read the short phrases and short sentences. } \\
\text { In teaching-learning process, the researchers summarized } \\
\text { activities that were provided by the teachers: 1) The Journey } \\
\text { to Letterland; 2) Letters' Recognition through storytelling; 3) } \\
\text { The Use of Teaching Aids; 4) Learning Through Games; 5) } \\
\text { Learning to Write Correct Letter Formation; 6) Learning the } \\
\text { five vowels; 7) The implementation of the tasks, and 8) The } \\
\text { Blending Task. }\end{array}$ \\
\hline
\end{tabular}

\section{Test Result Analysis}

There were eight tests given to the students. Each test represented each skill in acquiring Basic English literacy. The tests were analyzed to find out the role of Letterland in helping students acquire basic literacy. In conducting a careful analysis, the researcher categorized the abilities of students into five areas: 1) Learning Letters' shapes and Correct Information; 2) Learning Letters' sounds: Initial, medial, and final sounds; 3) Reading and Writing words with CVC; 4) Distinguish Words that Rhyme; 5) Reading Short Phrases with CVC. The following is the summary of the test analysis.

\begin{tabular}{|c|c|}
\hline Category & Analysis \\
\hline $\begin{array}{l}\text { Learning Letter Shapes and Correct } \\
\text { Formation }\end{array}$ & 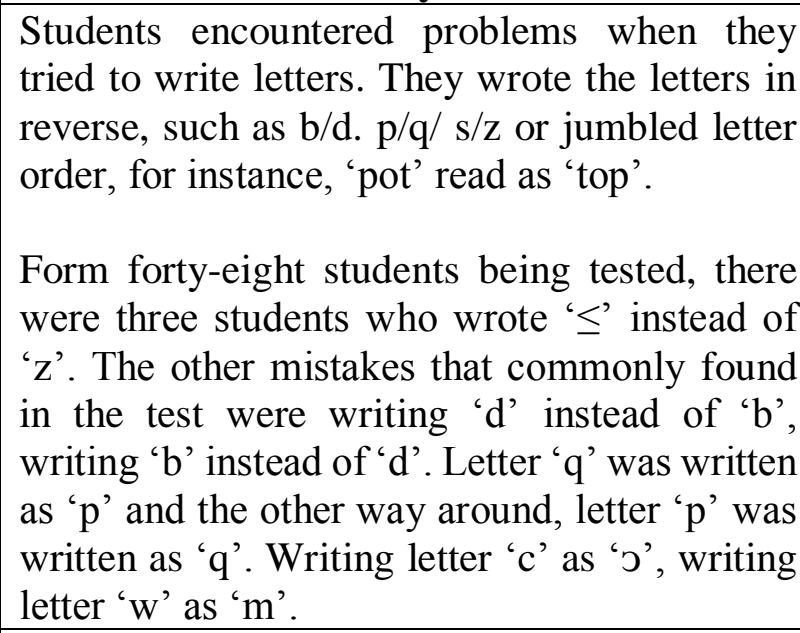 \\
\hline Learning Letter Sounds & $\begin{array}{l}\text { In this test, the students were expected to } \\
\text { recognize the initial, medial and final sounds. } \\
\text { The result shown, that most of the students } \\
\text { were able to recognize and write the correct } \\
\text { initial, medial and final sounds in CVC blends. } \\
\text { Initial sounds } \\
\text { In the test, the students recognized the pictures } \\
\text { and named them through the initial sounds, and } \\
\text { wrote the initial sound on the line provided. } \\
\text { The mistakes that the students made was in } \\
\text { letter formation, and inability to name the } \\
\text { pictures. } \\
\text { Medial Sounds } \\
\text { The test results showed that the students were } \\
\text { not able to distinguish the sound of 'a' which } \\
\text { sounds as /æ/ in 'hat' and the sound of 'e' } \\
\text { which sound as /e/ in 'ten'. Most of them have } \\
\text { not fully mastered the five vowel sounds, it was } \\
\text { seen from CVC blends through the given } \\
\text { pictures. } \\
\text { Final Sounds } \\
\text { Before giving the test to the students, the } \\
\text { teachers introduced pictures or vocabulary that }\end{array}$ \\
\hline
\end{tabular}




\begin{tabular}{|l|l|}
\hline & $\begin{array}{l}\text { matched the pictures. For instance, there was a } \\
\text { picture of a man and the students were required } \\
\text { to fill in the blank of the question: ma } \\
\text { matching the picture and the word by filling in } \\
\text { the blank with final sound. The picture helped } \\
\text { the students to recognize the final sound as } \\
\text { seen in the result of the study; wherein, most } \\
\text { students were able to answer the questions } \\
\text { properly. }\end{array}$ \\
$\begin{array}{l}\text { Initial and Final Sounds } \\
\text { The students were given nine pictures and they } \\
\text { should name the pictures by filling the initial } \\
\text { and final sounds that were missing. When the } \\
\text { students are given the picture of a pig, they } \\
\text { should fill the initial and final sound, } \\
\text { Most students were able to fill in the blanks } \\
\text { through the given pictures. }\end{array}$ \\
\hline Read Short Phrases with CVC Blends \\
Initial, Medial and Final Sounds \\
\hline Weading and Writing CVC & $\begin{array}{l}\text { After giving various tests about letter sounds, } \\
\text { the students were able to write three-letter word } \\
\text { even without being given a picture to match the } \\
\text { sord. } \\
\text { some easy prepositions which were often used } \\
\text { in phrases such as in, on, and at. In the test, the } \\
\text { students were required to match 10 phrases } \\
\text { with the correct pictures by reading the phrases } \\
\text { thoroughly. Most students were able to read the } \\
\text { given short phrases. }\end{array}$ \\
\hline $\begin{array}{l}\text { The test result on the initial, medial and final } \\
\text { sounds had given a picture of the capability of } \\
\text { the students on reading and writing the CVC } \\
\text { blends properly and fluently. Conclusively } \\
\text { most students were able to recognize the initial, } \\
\text { medial and final sounds. }\end{array}$ \\
$\begin{array}{l}\text { The students were able to recognize words that } \\
\text { rhyme, for instance 'cat', 'can', 'hat'. Most } \\
\text { students circled the word 'cat' and 'hat' which }\end{array}$ \\
\hline Rhyme
\end{tabular}

The researcher concluded that by implementing Letterland in helping students to read and write, basic literacy can be acquired. As stated by Cameron (2001), it is essential to remember that every child needs qualified teachers to help them become literate because incapable teachers contribute in students' failure. By all means, Letterland should be performed by knowledgeable teachers of literacy. 


\section{REFERENCES}

Anita, T. (2008). Teaching reading through the phonics approach to kindergarten students: A Case Study. Jakarta: Universitas Katolik Indonesia Atmajaya.

Blevins, W. (2001). Teaching phonics and word study in the intermediate grades: a complete sourcebook. New York: Scholastic Professional Books.

Cameron, L. (2001). Teaching langauges to young learners. New York: Cambridge University Press.

Campbell, S., Torr, J., Cologon, K. (2014). Pre-packaging Preschool Literacy: What Drives Early Childhood Teachers to Use Commercially Produced Phonics Program in Prior to School Settings. Contemporary Issues in Early Childhood. 15 (1). 40-53

Cook, v. (2004). The English writing system. London, UK: Arnold Publishers.

Daswani, C.K. (1999). Literacy an oracy: literacy. In Spolsky, B. Concise Encyclopedia of Educational Linguistics. Selected reading. 159-166. Cambridge Unviersity Press, UK>

Garton, A.F. \& Pratt, C. (1998). Learning to be literate: the developmental of spoken and written language. Blackwell Publishers: Oxford UK.

Green, C. (1990). Assessing kindergarten children's writing's dimensions.

Katemba, C.,V., \& Samuel (2017). Improving Student's Reading Comprehension Ability Using Jigsaw 1 Technique . Acuity : Journal of English Language Pedagogy,

Literature and Culture Vol 2 No.2 2017

http://jurnal.unai.edu/index.php/acuity/article/view/613/468

Leong, C.K \& Randhawa, B.S. (2012) (Eds). Understanding Literacy and Cognition: Theory, Research, and Application. Springer.

Maharani, P. (2007). Applying synthetic phonics on teaching reading to children. Jakarta: Unversitas Katolik Indonesia Atmajaya.

Piazza, C.L. (1987). Identifying context variables in research on writing: A review and suggested directions. Written Communication. Vol. 4.

Poulson, L. et.al. (2001). The theoretical beliefs of effective teachers of literacy in primary schools: and exploratory study of orientations to reading and wrting. Research Papers in Education. 16 (3). 271-292.

Smith, F. (1982). Understanding reading: a psycholinguistic analysis of reading and learning to read. New York: CBS College Publishing.

Wendon, L. (1999). Letterland: teachers' guide. Cambridge: Letterland International.

Widdowson, H.G. (1971). Language teaching texts: a manual for teachers. Oxford: University Press.

Wray, D. \& Medwell, J. (2014). Literacy and language in the primary years. Routledge. 